\title{
Correlations of intake, digestibility and performance with the ingestive behavior of lambs fed diets containing ammoniated buffel grass hay ${ }^{1}$
}

\section{Correlações entre consumo, digestibilidade e desempenho com o comportamento ingestivo de cordeiros alimentados com dietas contendo feno de capim-buffel amonizado}

\author{
Alexandre Fernandes Perazzo ${ }^{2 *}$; Sansão de Paula Homem Neto ${ }^{3}$; \\ Ossival Lolato Ribeiro ${ }^{4}$; Edson Mauro Santos ${ }^{5}$; Gleidson Giordano Pinto de Carvalho ${ }^{6}$; \\ Juliana da Silva Oliveira5; Thomaz Cyro Guimarães de Carvalho Rodrigues; \\ Ricardo Martins Araujo Pinho ${ }^{8}$
}

\begin{abstract}
This study aimed to evaluate the correlations of intake, digestibility and performance with the ingestive behavior of lambs fed diets containing ammoniated buffel grass hay. Buffel grass hay was treated with four levels of urea $(0,18,36$ and $54 \mathrm{~g} / \mathrm{kg}$ DM basis) and eight repetitions. Thirty-two sheep with no defined breed and an average body weight of $17.7 \pm 1.8 \mathrm{~kg}$ were distributed in a completely randomized design. It was observed positive correlations were found between the feeding time and the intake of dry matter $(r=0.3120)$, organic matter $(r=0.3242)$, neutral detergent fiber $(r=0.3800)$, total carbohydrates $(\mathrm{r}=0.3343)$ and total digestible nutrients $(\mathrm{r}=0.3233)$. Positive correlations $(\mathrm{P}<0.05)$ were found among the rumination efficiencies, $g$ of $\mathrm{DM} / \mathrm{h}$ and $\mathrm{g}$ of $\mathrm{NDF} / \mathrm{h}$ with nutrient intake variables, except for ether extract intake. Positive correlations were observed $(\mathrm{P}<0.05)$ between both total weight gain (TWG) and average daily gain (ADG) and the rumination efficiency, $g$ of $\mathrm{DM} / \mathrm{h}(\mathrm{r}=0.3330)$ and $\mathrm{g}$ of $\mathrm{NDF} / \mathrm{h}(\mathrm{r}=0.3304)$. The feeding and rumination efficiencies have a positive relationship with the total digestible nutrients. The correlation among intake, digestibility and performance variables with the ingestive behavior, it was important for the understanding of diet containing ammoniated buffel grass hay, in which the positive correlation of rumination efficiency with intake and weight gain explained the favorable effect on productive performance of feedlot sheep.
\end{abstract}

Key words: Feeding time. Nutrient intake. Rumination efficiency. Weight gain.

${ }^{1}$ Parte da Tese de Doutorado do primeiro autor.

2 Discente do Curso de Doutorado do Programa de Pós-Graduação em Zootecnia, Universidade Federal da Bahia, UFBA, Salvador, BA, Brasil. E-mail: alexandreperazzo@hotmail.com

${ }^{3}$ Discente do Curso de Doutorado do Programa de Pós-Graduação em Zootecnia, Universidade Estadual do Sudoeste da Bahia, UESB, Itapetinga, BA, Brasil. E-mail: sansaozootecniaufpb@hotmail.com

${ }^{4}$ Prof., Universidade Federal do Recôncavo da Bahia, UFRB, Cruz das Almas, BA, Brasil. E-mail: ossribeiro@yahoo.com.br

${ }_{5}^{5}$ Profs., Universidade Federal da Paraíba, UFPB, Areia, PB, Brasil. E-mail: edsonzootecnista@yahoo.com.br; oliveirajs@yahoo. com.br

${ }^{6}$ Prof., Universidade Federal da Bahia, UFBA, Salvador, BA, Brasil. E-mail: gleidsongiordano@yahoo.com.br

7 Discente do Curso de Doutorado do Programa de Pós-Graduação em Zootecnia, UFBA, Salvador, BA, Brasil. E-mail: thomazguimaraes@yahoo.com.br

${ }^{8}$ Discente do Curso de Doutorado do Programa de Pós-Graduação em Zootecnia, UFPB, Areia, PB, Brasil. E-mail: ricardozootec@hotmail.com

* Author for correspondence 


\section{Resumo}

Objetivou-se avaliar as correlações entre o consumo, digestibilidade e desempenho com o comportamento
ingestivo de cordeiros confinados alimentados com dietas contendo feno de capim-buffel amonizado. Os
tratamentos experimentais consistiram em quatro dietas contendo os fenos de capim-buffel amonizados
com as diferentes concentrações de uréia $(0,18,36$ e $54 \mathrm{~g} / \mathrm{kg}$ na MS) e oito repetições. Foram utilizados
32 ovinos sem padrão racial definido (SPRD), com peso vivo médio de $17,7 \pm 1,8 \mathrm{~kg}$, distribuídos em
delineamento experimental inteiramente casualizado (DIC). Foram verificadas correlações positivas
entre o tempo de alimentação e os consumos: de matéria seca $(\mathrm{r}=0,3120)$, matéria orgânica $(0,3242)$,
fibra em detergente neutro $(\mathrm{r}=0,3800)$, carboidratos totais $(\mathrm{r}=0,3343)$ e nutrientes digestíveis totais
$(\mathrm{r}=0,3233)$. Correlações positivas $(\mathrm{P}<0,05)$ foram encontradas entre as eficiências de ruminação, g MS/h
e g FDN/h, com as variáveis de consumo de nutrientes, exceto para consumo de extrato etéreo. Indicando
conformidade dos resultados com as variáveis de consumo, foram observadas correlações positivas
$(\mathrm{P}<0,05)$ encontradas para ganho de peso total e ganho médio diário entre as eficiências de ruminação, g
MS/h $(\mathrm{r}=0,3330)$ e g FDN $/ \mathrm{h}$ ( $\mathrm{r}=0,3304)$. As eficiências de alimentação e ruminação apresentam relação
positiva com os nutrientes digestíveis totais. O estudo da correlação entre as variáveis foi importante
para o entendimento da dieta contendo feno de capim-buffel amonizado, onde a correlação positiva da
eficiência de ruminação com consumo e ganho de peso explicaram o efeito favorável no desempenho
produtivo de ovinos confinados.
Palavras-chave: Consumo de nutrientes. Eficiência de ruminação. Ganho de peso. Tempo de alimentação.

\section{Introduction}

Ammonization has been proven to be an efficient method to improve the nutritional value of hay forage grasses from plants harvested during an advanced stage of development, decreasing the fiber content and increasing the digestibility and intake of diets (REIS et al., 2001; FERNANDES et al., 2002). Ammonization may also result in increased levels of nitrogen compounds in the treated waste that is attributed to the nitrogen content of the used products, which favors the development of rumen microorganisms, including cellulolytic bacteria whose main source of nitrogen is ammonia (GOMES et al., 2009).

The nature of the diet, in addition to causing effects on consumption, can also influence the feeding behavior and the rumination time, which are proportional to the cell wall content ingested by the animals (VAN SOEST, 1994). There are also limitations to the dietary energy level and to the palatability of foods, such as sour and bitter taste and strong odors. Dado and Allen (1994) highlight the importance of measuring eating behavior and rumination to verify the implications on daily food consumption.
Knowledge of feeding behavior, according to the given diet, is very important to evaluate productive performance. Missio et al. (2010), in addition to measuring consumption, used performance data to assess the animal's response to dietary consumption. Therefore, because of the relevance in interpreting the effects found in the literature, the number of feeding behavior studies of ruminants has increased considerably (SANTANA JÚNIOR et al., 2012).

The existence of possible correlations between production and behavioral variables can guide further work to build models to predict intake and digestibility by feeding behavior.

The objective of this study was to evaluate the correlation of the intake, digestibility and performance with the feeding behavior of feedlot lambs fed diets containing ammoniated buffel grass hay.

\section{Materials and Methods}

The experiment was conducted in the Pending Experimental Station, the Agricultural Research 
Company of Paraíba SA (EMEPA), located at Mesoregion do Agreste Paraibano, micro-region of West Curimataú, municipality of Soledad-PB, in Brazil, (7th 8'18 'S and $36^{\circ} 27^{\prime} 2$ ' 'W), at an altitude of $534 \mathrm{~m}$. The trial took place between September and November 2012.

During the pre-trial period the animals were weighed, wormed and underwent a period of 15 days of adaptation to confinement and the inclusion of urea in their diets. Also during this period, the hay was ammoniated. The haying process was finished in August 2012 in the traditional method using buffel grass harvested at the beginning of the dry season in a pasture not grazed during the rainy season and planted at the aforementioned experimental station. To make the hay, the grass was harvested using a brush cutter machine (model RN27L, NAGANO) and dried in the sun until it reached the hay point.
The ammonization process was performed by initially weighing the hay bales to calculate the amount of urea that should be added to give proportions of $0,18,36$ and $54 \mathrm{~g} / \mathrm{kg}$ dry matter (DM). Urea was then diluted with water and applied uniformly to moisten all of the material being put in plastic canvas. After 30 days, the hay was opened and given to the animals after 24 hours of outdoor exposure.

Thirty-two male sheep with no defined breed (SPRD) and an average live weight of $17.7 \pm 1.8$ $\mathrm{kg}$ were distributed in a completely randomized design (CRD), where the animals were submitted to the experimental treatments consisted of four diets containing buffel grass hay ammoniated with different proportions of urea $(0,18,36$ and $54 \mathrm{~g} /$ $\mathrm{kg}$ DM basis) and eight repetitions. The diets were formulated to be isonitrogenous and to meet the requirements for an average daily gain of $0.2 \mathrm{~kg}$ according to NRC (2007) (Tables 1 and 2).

Table 1. Chemical composition of the ingredients of experimental diets.

\begin{tabular}{|c|c|c|c|c|c|c|}
\hline \multirow{3}{*}{ Item $(\mathrm{g} / \mathrm{kg} \mathrm{DM})^{1}$} & \multicolumn{4}{|c|}{ Ammoniated buffel grass hay } & \multirow{3}{*}{$\begin{array}{c}\text { Soybean } \\
\text { meal }\end{array}$} & \multirow{3}{*}{ Corn meal } \\
\hline & \multicolumn{4}{|c|}{ Level of urea $(\mathrm{g} / \mathrm{kg})$} & & \\
\hline & 0 & 18 & 36 & 54 & & \\
\hline $\mathrm{DM}$ & 850.7 & 841.6 & 830.5 & 831.0 & 913.2 & 901.1 \\
\hline $\mathrm{OM}$ & 892.0 & 870.3 & 910.6 & 890.5 & 934.5 & 984.5 \\
\hline $\mathrm{CP}$ & 23.0 & 46.4 & 63.3 & 78.2 & 453.9 & 99.2 \\
\hline $\mathrm{EE}$ & 7.9 & 11.6 & 9.9 & 12.4 & 24.9 & 45.6 \\
\hline NFC & 94.3 & 64.5 & 69.6 & 64.8 & 317.1 & 721.3 \\
\hline NDF & 747.2 & 740.9 & 751.7 & 735.1 & 138.6 & 118.4 \\
\hline NDIP & 25.4 & 33.0 & 32.2 & 31.0 & 422.5 & 87.3 \\
\hline $\mathrm{TC}$ & 841.5 & 805.4 & 821.3 & 799.9 & 45.7 & 839.7 \\
\hline $\mathrm{ADF}$ & 530.1 & 514.5 & 536.4 & 514.9 & 98.6 & 40.8 \\
\hline Hemicellulose & 217.1 & 226.4 & 215.3 & 220.2 & 40.0 & 77.6 \\
\hline Cellulose & 477.2 & 463.2 & 482.9 & 463.6 & 85.3 & 29.2 \\
\hline Lignin & 52.9 & 51.3 & 53.5 & 51.3 & 13.3 & 11.6 \\
\hline Ash & 108.0 & 129.6 & 89.3 & 109.4 & 60.2 & 15.5 \\
\hline
\end{tabular}

$\mathrm{DM}=$ dry matter; $\mathrm{OM}=$ organic matter; $\mathrm{CP}=$ crude protein; $\mathrm{EE}=$ ether extract; $\mathrm{NFC}=$ non fibrous carbohydrate $\mathrm{NDF}=$ neutral detergent fiber; $\mathrm{NDIP}=$ neutral detergent insoluble protein; $\mathrm{TC}=$ total carbohydrate; $\mathrm{ADF}=$ acid detergent fiber. 
The diets were fed twice daily at 9:00 and 16:00, ad libitum, to allow for 10 to $20 \%$ leftovers. Samples of the foods offered and the remains were collected weekly, subsequently, were pre-dried in a pre-drying oven at $60{ }^{\circ} \mathrm{C}$, ground in a mill with a $1 \mathrm{~mm}$ sieve, packed in plastic pots with lids and stored in a freezer at $-20^{\circ} \mathrm{C}$ for further analysis.

The ingredients, diets and the leftovers were analyzed to determine the levels of dry matter
(DM), mineral matter (MM), crude protein (CP) and ether extract (EE) according to AOAC (1990). To estimate the values of the neutral detergent fiber (NDF) and acid detergent fiber (ADF), we used the method of Van Soest et al. (1991). The NDF was corrected for ash and protein. The lignin levels were obtained according to the methodology of Silva and Queiroz (2002), with the ADF (acid detergent fiber) residue treated with $72 \%$ sulfuric acid.

Table 2. Proportion of ingredients and chemical composition of the experimental diets offered to the lambs.

\begin{tabular}{|c|c|c|c|c|}
\hline \multirow{3}{*}{ Ingredients (g/kg DM)) } & \multicolumn{4}{|c|}{ Ammoniated buffel grass hay } \\
\hline & \multicolumn{4}{|c|}{ Level of urea $(\mathrm{g} / \mathrm{kg} \mathrm{MS})$} \\
\hline & 0 & 18 & 36 & 54 \\
\hline Buffel grass hay & 485 & 511 & 523 & 536 \\
\hline Corn meal & 382 & 365 & 358 & 350 \\
\hline Soybean meal & 95 & 90 & 89 & 87 \\
\hline Calcareous & 5 & 4 & 4 & 4 \\
\hline Mineral supplement & 17 & 16 & 16 & 15 \\
\hline Urea & 8 & 5 & 2 & 0 \\
\hline \multirow[t]{2}{*}{ Ammonium chloride } & 8 & 8 & 8 & 8 \\
\hline & \multicolumn{4}{|c|}{ Bromatological composition (g/kg DM) } \\
\hline Dry matter ( $\mathrm{g} / \mathrm{kg}$ fresh matter) & 881.5 & 874.1 & 868.2 & 867.2 \\
\hline Organic matter & 897.4 & 888.1 & 911.8 & 903.1 \\
\hline Crude protein & 127.4 & 127.9 & 127.7 & 129.2 \\
\hline Ether extract & 23.6 & 24.8 & 23.7 & 24.7 \\
\hline Neutral detergent fiber & 420.7 & 434.2 & 447.8 & 447.5 \\
\hline Acid detergent fiber & 282.0 & 286.6 & 303.9 & 298.8 \\
\hline Non fibrous carbohydrate & 351.3 & 324.7 & 322.8 & 314.7 \\
\hline Total Carbohydrate & 772.1 & 759.0 & 770.7 & 762.2 \\
\hline Ash & 102.6 & 111.9 & 88.2 & 96.9 \\
\hline $\mathrm{NDIP}^{2}$ & 85.8 & 86.8 & 85.7 & 84.0 \\
\hline Cellulose & 250.7 & 256.0 & 270.9 & 266.1 \\
\hline Hemicellulose & 138.7 & 147.6 & 143.9 & 148.7 \\
\hline Lignin & 31.3 & 31.6 & 33.3 & 32.7 \\
\hline $\mathrm{iNDF}^{3}$ & 257.4 & 245.8 & 241.9 & 251.3 \\
\hline
\end{tabular}

Assurance levels (per kg active elements): calcium - 120.00 g; phosphorus - 87.00 g; sodium - 147.00 g; sulfur - 18.00 g; copper $590.00 \mathrm{mg}$; cobalt - $40.00 \mathrm{mg}$; chromium - $20.00 \mathrm{mg}$; iron - 1,800.00 mg; iodine - $80.00 \mathrm{mg}$; manganese - 1,300.00 mg, selenium - $15.00 \mathrm{mg}$; zinc - 3,800.00 mg; molybdenum - $300.00 \mathrm{mg}$; maximum fluoro - $870.00 \mathrm{mg}$; solubility of phosphorus (P) citric acid $2 \%$ low $-95 \%$. 2 neutral detergent insoluble protein; 3 indigestible NDF. 
According to the methodology described by Mertens (1997), the non-fiber carbohydrate levels (NFC) in the food were estimated considering the NDF corrected for ash and protein. The protein content neutral detergent insoluble (PNDI) was obtained according to the methodology of Licitra et al. (1996).

The percentage of TC (total carbohydrates) was calculated according to Sniffen et al. (1992) and of NFC (non-fiber carbohydrate) by the difference between total carbohydrate and neutral detergent fiber.

$$
\begin{aligned}
& T C=100-(\% C P+\% E E+\% a s h) \\
& N F C=T C-N D F
\end{aligned}
$$

The total digestible nutrients (TDN) content was calculated according to the equation proposed by Weiss (1999):

$$
T D N=D C P+(2,25 x E E D)+D N
$$

Where, $\operatorname{TDN}(\mathrm{g} / \mathrm{kg})=$ total digestible nutrients, $\mathrm{DCP}=$ digestible crude protein, $\mathrm{EED}=$ ether extract digestible, DNFC = digestible non-fibrous carbohydrates, and NDFcpD = neutral detergent fiber corrected for ash and digestible protein.

The individual consumption was analyzed over the 49 days of feeding of the experimental diets by subtracting the leftovers amount of diet offered to each animal. Thus, DM, OM, CP, NDF, TC, NFC, $\mathrm{EE}$ and TDN were evaluated and expressed in grams/animal/day (g/d). The chemical composition of the consumed food was obtained by dividing the consumption of each nutrient consumption by the DM and 100 and then multiplying the quotient.

For the performance evaluation, the individual weight of each animal was recorded at the start of the trial period and every 14 days following to a $12-\mathrm{h}$ fast of solid food. At the end of the trial period the feed conversion and feed efficiency were calculated. The feed efficiency was obtained by dividing the weight gain by dry matter intake recorded during the harvest period, while the feed conversion was obtained by dividing the dry matter intake by the body weight gain.

For five days, aliquots of stool samples and the supplied food were collected at alternate times. The determination of fecal dry matter production was calculated through the internal marker indigestible neutral detergent fiber (iNDF) according to the methodology described by Berchielli et al. (2000). Thus, for the determination of fecal dry matter production (DFMP) using an internal marker, the following equation was used:

$D F M P=$ consumption indicator/concentration of indicator in the feces

The digestibility determination was calculated using the following equation described by Berchielli et al. (2000), wherein the digestibility coefficient (DC), measured in $\mathrm{g} / \mathrm{kg}$, was calculated by:

\section{$D C=$ (Nutrient intake - nutrient excreted) $x$ 1000 / nutrient intake}

To evaluate the feeding behavior, the animals were subjected to visual observation for a period of 24 hours every 14 days trial period. The observations were made in five-minute intervals to evaluate the feeding, ruminating and idle times. During the night, the observations were carried out under artificial lighting. On the same day, three observations of each animal were divided into the following three periods: morning, afternoon and evening. During these periods, the number of chews per ruminal bolus and the time spent ruminating each bolus was observed. Data on the time spent on each activity was collected with the aid of digital timers, handled by four observers, which were arranged so as not to interfere in the behavior of the animals.

To estimate the behavioral variables of feed and rumination ( $\mathrm{min} / \mathrm{kg} \mathrm{DM}$ and NDF), feed efficiency (g DM and NDF/h) and average intake of DM and NDF by feeding period, we used the DM voluntary intake and NDF the 13th and 14th days of each experimental period computed from the leftovers on the 15th day of each sub-period. The behavior 
variables data were obtained according to the methodology described by Bürger et al (2000).

The number of boli ruminated daily was calculated by dividing the total rumination time ( $\mathrm{min}$ ) by the average time spent on the rumination of a bolus.

For the concentration of DM and NDF in each ruminated bolus (g), the quantity of DM and NDF consumed (g) during 24 hours was divided by the number of boli ruminated per day.

The feed and rumination efficiencies were obtained as follows:

$$
\begin{aligned}
& D M F E=\frac{D M I}{F E E D} \\
& \text { NDFFE }=\frac{N D F I}{F E E D}
\end{aligned}
$$

in which DMFE is the feed efficiency as g DM consumed hour ${ }^{-1}$, NDFFE is the feed efficiency as $g$ NDF consumed hour ${ }^{-1}$, DMI and NDFI are the daily intakes of dry matter and neutral detergent fiber, respectively, and FEED is the time spent feeding per day.

$$
\begin{aligned}
& D M R E=\frac{D M I}{R U M} \\
& \text { NDFRE }=\frac{N D F I}{\square} R M
\end{aligned}
$$

in which DMRE is rumination efficiency as $g$ $\mathrm{DM}$ ruminated/hour, NDFRE is the rumination efficiency as $\mathrm{g}$ NDF ruminated/hour, DMI and NDFI are the daily intakes of dry matter and neutral detergent fiber, respectively, and RUM is the time spent ruminating per day.

$$
T C T=F E E D+R U M
$$

in which TCT is the total chewing time, as min/ day.

The number of ruminating and idle feeding periods was counted by watching the sequence number of activities on the note sheet. The average daily time of each period was calculated by dividing the total duration of each activity (eating, ruminating and idling) by their respective number of periods.
The study of the correlation between intake, digestibility, animal performance and behavior were interpreted through analysis of the Pearson linear correlation and processed by System for Statistical Analyses and Genetics - SAEG 9.1 (SAEG, 2007), considering $5 \%$ to be a critical level of probability.

\section{Results and Discussion}

Low correlations $(\mathrm{P}<0.05)$ were observed between feeding time and fuel consumption of the following: dry matter $(r=0.3120)$, organic matter $(r=0.3242)$, neutral detergent fiber $(r=0.3800)$ total carbohydrates $(r=0.3343)$ and total digestible nutrients $(\mathrm{r}=0.3233)$, as shown in Table 3 .

The positive correlation between the feeding activity and consumption variables may have been caused by the stimulus provided of the urea incorporation to the diet, increasing the intake, and simultaneously increases in feeding time. This behavior is due to rumination efficiency that provides greater intake in less time ruminating, promoting greater time spent for food (Table 3).

The consumption variables showed no correlation $(\mathrm{P}>0.05)$ with rumination, idleness and total chewing time. Behavioral activities are mutually exclusive, so when the time spent on feeding increases, there is a consequent decrease in the time spent on other activities. For this reason, the correlation between parameters related to non-feeding behaviors and the nutrients intake cannot be independently evaluated.

According to Welch and Hooper (1988), rumination time is highly correlated $(r=0.96)$ with the NDF intake. Thus, the higher the NDF intake, the greater the time taken to ruminate. In the current study, there was positive correlation $(r=0.380)$ for NDF intake only with feeding time, being explained by rumination efficiency due incorporation of NPN (nonprotein nitrogen) sources to the diet favoring a higher degree of degradation of the different fiber fractions, thus stimulating feeding activity (BERCHIELLI et al., 2011) and decreasing rumination time. 


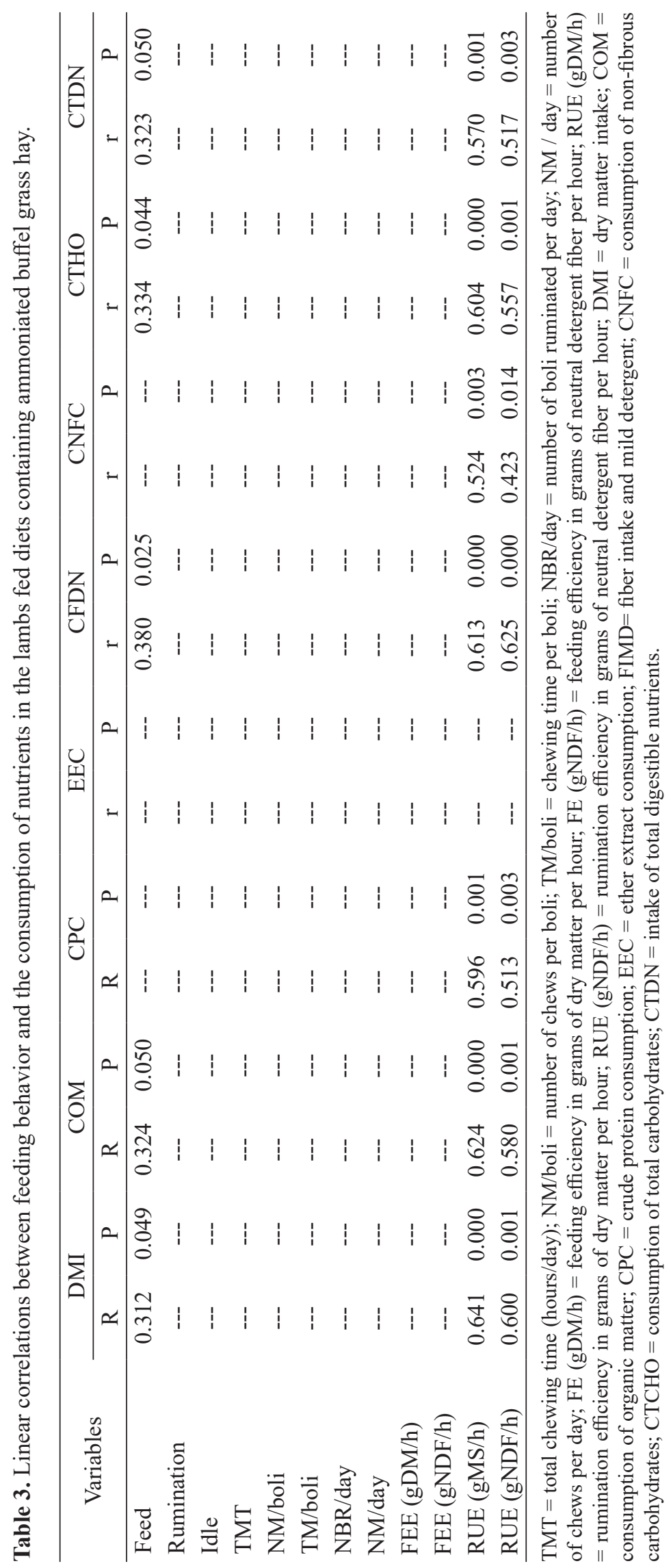


The chewing process is very important not only to reduce the particle size but also to produce cracks serving as a gateway for the rumen microorganisms (CARVALHO et al., 2008). Linear correlations among number and chewing time per boli, number of boli ruminated per day and chewing number per day did not affect significant $(\mathrm{P}>0.05)$ among nutrients intake (Table 3 ). As reported by Rabelo et al. (2008), the time spent chewing increases as the NDF fiber supply rises due to the increase in the time spent chewing and the decrease in dry matter intake. Because to the similar values in the fiber diet levels (Table 2) it was not possible to find correlations between the effects of chewing and nutrients intake.

The nutrients intake were not correlated $(\mathrm{P}>0.05)$ with the feed efficiencies, expressed in g DM/h NDF/h; however, positive correlations $(\mathrm{P}<0.05)$ were found between the rumination efficiency, $g \mathrm{DM} / \mathrm{h}$ and $\mathrm{NDF} / \mathrm{h}$ and nutrient consumption variables, except for ether extract consumption.

The values indicate that the effects on nutrient intake rates are not necessarily linked to the feed efficiency. According to Bürger et al. (2000), the efficacy of rumination is important for the control of food utilization, and thus, the ruminating animal with satisfactory activity has a higher consumption and improves productivity.

According to Dulphy et al. (1980), rumination efficiency improves when the diet concentrate increases. The use of NPN sources in the diet, through hay ammonization and urea in the concentrate, probably favored a greater rumination efficiency due to the increase in the cellulolytic activity of the ruminal microorganisms, providing greater nutrients intake by rumen emptying.
However, the regulation of nutrient intake is also associated with NDF, which is responsible for the effect of the physical filling of the rumen. Thus, the better the rumination efficiency of the fiber, the faster the rumen empties, promoting therefore higher consumption (BERCHIELLI et al., 2011).

Feeding times, rumination and total chewing showed no correlation $(\mathrm{P}>0.05)$ with any of the digestibility variables. There was a positive correlation $(\mathrm{P}<0.05)$ of the idle time between the organic matter digestibility $(r=0.3721)$ and total carbohydrates $(r=0.3538)$ in accordance with Table 4.

In preliminary studies, the diets have high digestibility coefficients, which possibly resulted in the increase time spent idle. Meeting the nutritional requirements or the control in food intake for energy supply explains the increase time spent idle, suggesting that the animals ingested more digestible diets. This fact was observed in this study due to the organic matter and total carbohydrates digestibilities.

However, the digestibility of nutrients was not responsible for the control of feeding time. Although the diets offered were high in NDF (Table 2) and NPN, the digestibility of the nutrients was not correlated with rumination activity and total chewing.

The nutrient digestibility coefficients when observed with chewing activities described in the number of chews per bolus ( $\mathrm{NC} /$ bolus), the chewing time per bolus (CT/bolus), the number ruminated per day (NR/day) and the number of chews per day (NC/day), showed no significant correlations ( $\mathrm{P}>0.05$ ) except between digestibility of crude protein and number of boli per day, $r=-0.3826$ (Table 4). 


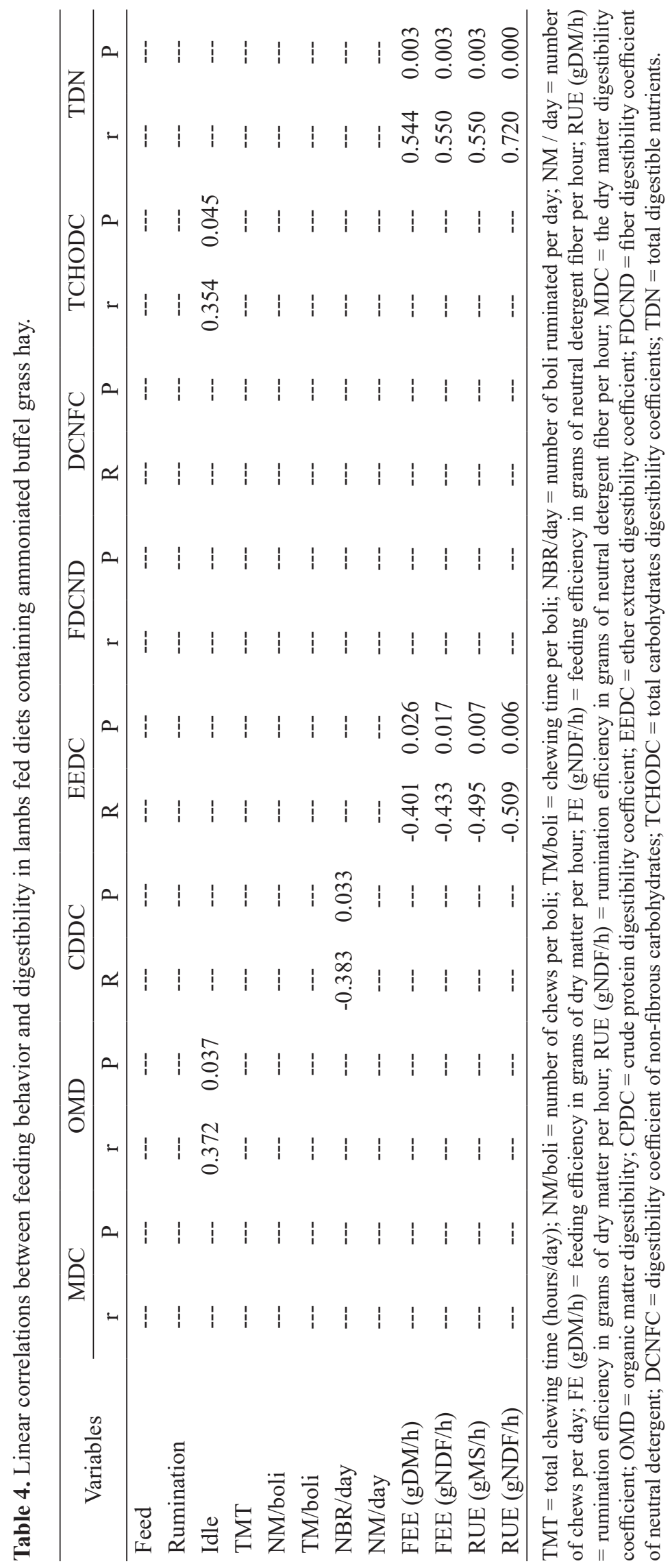


There is a strong dependence chewing aspects associated with time spent ruminating (BÜRGER et al., 2000). The absence of significant effects of correlation between rumination times, in the study, explain the inexistence of correlation between chewing aspects with intake and nutrients digestibility.

The digestibility coefficients of DM, OM, CP, NDF, NFC and TC were not correlated $(\mathrm{P}>0.05)$ with feeding efficiencies, expressed in $\mathrm{g} D \mathrm{DM} / \mathrm{h}$ and $\mathrm{NDF} / \mathrm{h}$, except for $\mathrm{EE}$ intake and total digestible nutrients. Similar results were found for the efficiency of rumination, expressed in $\mathrm{g} D \mathrm{DM} / \mathrm{h}$ and $\mathrm{NDF} / \mathrm{h}$ (Table 4).

The feed efficiencies, with $r=0.5440$ for $g$ $\mathrm{DM} / \mathrm{h}$ and $\mathrm{r}=0.5495$ for $\mathrm{g} \mathrm{NDF} / \mathrm{h}$, and ruminating, with $r=0.7501 \mathrm{~g}$ for $\mathrm{DM} / \mathrm{h}$ and $\mathrm{r}=0.7202$ for $\mathrm{g}$ $\mathrm{NDF} / \mathrm{h}$ positively interfere with the assimilation of total nutrients in the animals due to the diet. The nitrogen supply in the diet associated with TDN in adequate amounts provides the maintenance of microbial activity (MALLMANN et al., 2006), and this relationship allows the optimization of feed and the rumen environment (MATHIS et al., 2000).

The TDN was positively highly correlated with the efficiency of rumination, expressed in $\mathrm{g} D M / h$ and NDF/h, with an r-value above 0.7 , confirming previous trends about rumination importance in this study.

A positive correlation was verified $(\mathrm{P}<0.05)$ between the feeding time with TWG and ADG, both with $r=0.3111$. The rumination time showed the same tendency for the weight gain variables, with $r=0.3391$ for both variables (Table 5). This behavior was also found by Santana Júnior et al. (2013) evaluating heifers in the pasture. The authors explained that the increase in the body weight of the animal's organs also develop due to the increasing volumetric capacity of the rumen. Therefore, the increase in the body weight means higher ruminal capacity, consumption and, accordingly, rumination.

The TWG and ADG showed negative correlations $(\mathrm{P}<0.05)$ observed between leisure time, with $\mathrm{r}=$ -0.4565 for both. The total chewing time was not correlated $(\mathrm{P}>0.05)$ with the animal performance variables. As behavioral activities are mutually exclusive, a higher forage intake is necessary to increase the feeding time. The idle time afforded a negative correlation $(\mathrm{P}<0.05)$ to feed efficiency and positive to food conversion.

Certainly, the positive correlation between the feeding time and rumination with weight gain and ADG assumes satisfactory conditions of diet, which provided an increase in performance. The number of chews per bolus, the bolus chewing time and the number of chews per day showed no correlation $(\mathrm{P}>0.05)$ with animal performance variables. Positive correlations $(\mathrm{P}<0.05)$ were found only for the number of muffins per day ruminated between weight gain and average daily $(r=0.3946)$, feed efficiency $(r=0.4567)$ and feed conversion $(r=$ -0.4446).

The number of ruminal boli is dependent on the rumination time and the time spent ruminating each bolus. Therefore, this significant correlation shows that the animals were able to ingest larger amounts of nutrients by virtue of the increased number of boli ruminated per day, so there was possibly less need to ruminate, resulting in improved animal performance. 


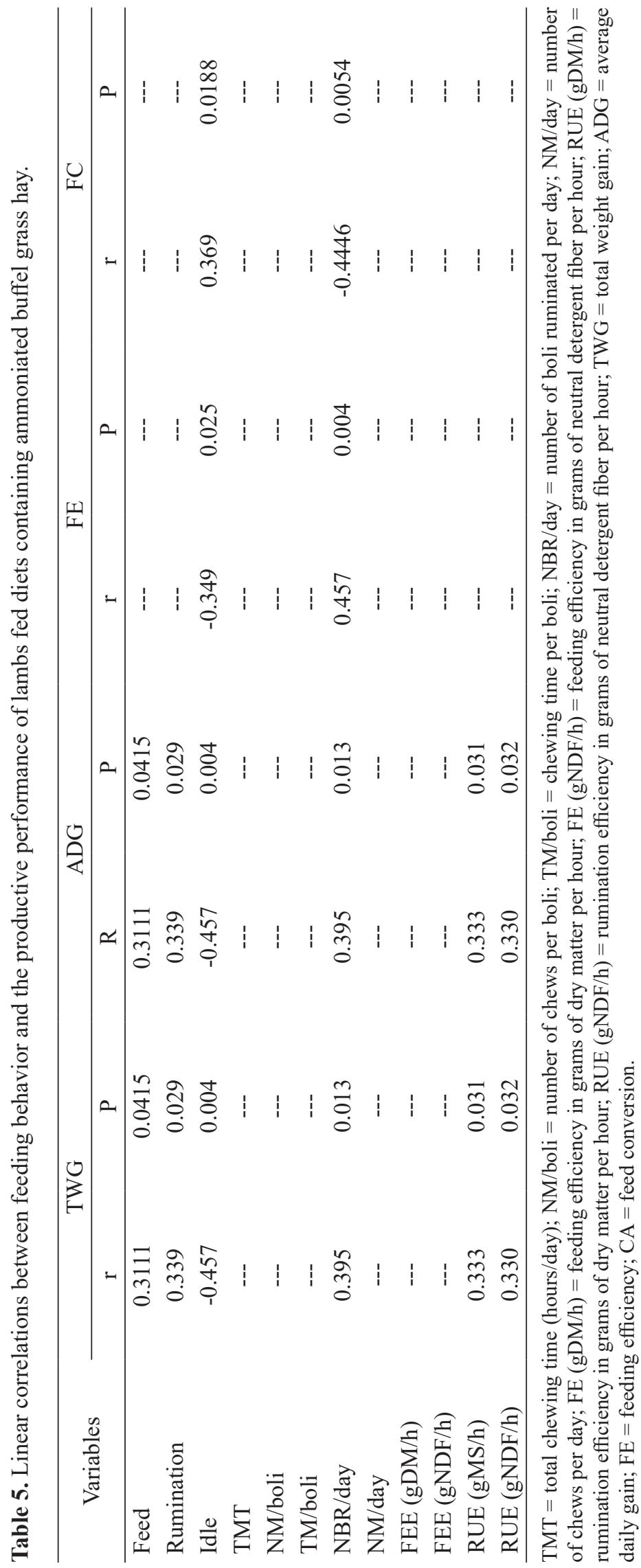


The performance variables were not correlated $(\mathrm{P}>0.05)$ with the feed efficiency, expressed in $\mathrm{g}$ $\mathrm{DM} / \mathrm{h} \mathrm{NDF} / \mathrm{h}$. Positive correlations were observed $(\mathrm{P}<0.05)$ for total weight gain and ADG between rumination efficiencies in $\mathrm{g} D \mathrm{DM} / \mathrm{h}(\mathrm{r}=0.3330)$ and $\mathrm{g} \mathrm{NDF} / \mathrm{h}(\mathrm{r}=0.3304)$, indicating conformity of the results with the use of variables (Table 5). The principle for animal production considers the nutritional requirements of individuals versus their nutrient intake, which depends upon their dry matter intake (CASTRO et al., 2007).

Rumination efficiency is an important mechanism in controlling the use of low nutritional value food (CARVALHO et al., 2004). Welch (1982) noted that the rumination efficiency has great importance in controlling the use of low quality food. The animal can chew larger amounts of food, providing increased food consumption and better production performance.

Thus, better rumination efficiency of the fiber can provide increased consumption of nutrients. Berchielli et al. (2011) noted that the dry matter intake is the most important variable that influences animal performance (MERTENS, 1997).

\section{Conclusions}

The correlation among intake, digestibility and performance variables with the ingestive behavior, it was important for the understanding of diet containing ammoniated buffel grass hay, in which the positive correlation of rumination efficiency with intake and weight gain explained the favorable effect on productive performance of feedlot sheep.

\section{References}

ASSOCIATION OF OFFICIAL ANALYTICAL CHEMISTS - AOAC. Official methods of analysis. $15^{\text {th }}$ ed. Washington, D.C: AOAC International, 1990.

BERCHIELLI, T. T.; ANDRADE, P.; FURLAN, C. L. Avaliação de indicadores internos em ensaio de digestibilidade. Revista Brasileira de Zootecnia, Viçosa, MG, v. 29, n. 3, p. 830-833, 2000.

BERCHIELLI, T. T.; VEGA-GARCIA, A.; OLIVEIRA, S. G. Principais técnicas de avaliação aplicadas em estudo de nutrição. In: BERCHIELLI, T. T.; PIRES, A. V.; OLIVEIRA, S. G. (Ed.). Nutrição de ruminantes. 2. ed. Jaboticabal: Funep, 2011. p. 565-600.

BÜRGER, P. J.; PEREIRA, J. C.; QUEIROZ, A. C.; COELHO, J. F.; AGOSTINI, P. S.; VALADARES FILHO, S. C.; CECON, P. R.; CASALI, A. D. P. Comportamento ingestivo de bezerros holandeses alimentados com dietas contendo diferentes níveis de concentrado. Revista Brasileira de Zootecnia, Viçosa, MG, v. 29, n. 1, p. 236242, 2000.

CARVALHO, G. G. P. de; PIRES, A. J. V.; SILVA, R. R.; RIBEIRO, L. S. O.; CHAGAS, D. M. T. Comportamento ingestivo de ovinos Santa Inês alimentados com dietas contendo farelo de cacau. Revista Brasileira de Zootecnia, Viçosa, MG, v. 37, n. 4, p. 660-665, 2008.

CARVAlHO, G. G. P. de; PIRES, A. J. V.; SILVA, F. F.; VELOSO, C. M.; SILVA, R. R.; SILVA, H. D. O.; BONOMO, P.; MENDONÇA, S. D. S. Comportamento ingestivo de cabras leiteiras alimentadas com farelo de cacau ou torta de dendê. Pesquisa Agropecuária Brasileira, Brasília, v. 39, n. 9, p. 919-925, 2004.

CASTRO, J. M. C.; SILVA, D. S.; MEDEIROS, A. N.; PIMENTA FILHO, E. C. Desempenho de Cordeiros Santa Inês alimentados com dietas completas contendo feno de maniçoba. Revista Brasileira de Zootecnia, Viçosa, MG, v. 36, n. 3, p. 674-680, 2007.

DADO, R. G.; ALLEN, M. S. Variation in and relationships among feeding, chewing, and drinking variables for lactating dairy cows. Journal of Dairy Science, Champaign, v. 77, n. 1, p. 132-144, 1994.

DULPHY, J. P.; REMOND, B.; THERIEZ, M. Ingestive behaviour and related activities in ruminants. In: RUCKEBUSH, Y.; THIVEND, P. (Ed.). Digestive physiology and metabolism in ruminants. Lancaster: MTP, 1980. p. 103-122.

FERNANDES, L. O.; REIS, R. A.; RODRIGUES, L. R. A.; LEDIC, I. L.; MANZAN, R. J. Qualidade do feno de Brachiaria decumbens Stapf. submetido ao tratamento com amônia anidra ou ureia. Revista Brasileira de Zootecnia, Viçosa, MG, v. 31, n. 3, p. 1325-1332, 2002.

GOMES, J. A. F.; LEITE, E. R.; CAVALCANTE, A. C. R.; CÂNDIDO, M. J. D.; LEMPP, B.; BOMFIM, M. A. D.; ROGÉRIO, M. C. P. Resíduo agroindustrial da carnaúba como fonte de volumoso para a terminação de ovinos. Pesquisa Agropecuária Brasileira, Brasília, v. 34, n. 1, p. 58-67, 2009. 
LICITRA, G.; HERNANDEZ, T. M.; VAN SOEST, P. J. Standardization of procedures for nitrogen fractionation of ruminant feeds. Animal Feed Science and Technology, Amsterdam, v. 57, n. 4, p. 347-358, 1996.

MALLMANN, G. M.; PATINO, H. O.; SILVEIRA, A. L. F.; MEDEIROS, F. S.; KNORR, M. Consumo e digestibilidade de feno de baixa qualidade suplementado com nitrogênio não protéico em bovinos. Pesquisa Agropecuária Brasileira, Brasília, v. 41, n. 2, p. 331-337, 2006.

MATHIS, C. P.; COCHRAN, R. C.; HELDT, J. S.; WOODS, B. C.; ABDELGADIR, I. E. O.; OLSON, K. C.; TITGEMEYER, E. C.; VANZANT, E. S. Effects of supplemental degradable intake protein on utilization of medium- to low-quality forages. Journal of Animal Science, Champaign, v. 78, n. 1, p. 224-232, 2000.

MERTENS, D. R. Creating a system for meeting the fiber requirements of dairy cows. Journal of Dairy Science, Champaign, v. 80, n. 7, p. 1463-1481, 1997.

MISSIO, R. L.; BRONDANI, I. L.; ALVES FILHO, D. C.; SILVEIRA, M. F.; FREITAS, L. S.; RESTLE, J. Comportamento ingestivo de tourinhos terminados em confinamento, alimentados com diferentes níveis de concentrado na dieta. Revista Brasileira de Zootecnia, Viçosa, MG, v. 39, n. 7, p. 1571-1578, 2010.

NATIONAL RESEARCH COUNCIL - NRC. Nutrient requirements of small ruminants: sheep, goats, cervids and new world camelids. Washington, D.C.: National Academies Press, 2007.

RABELO, M. M.A.; PIRES, A. V.; SUSIN, I.; MENDES, C. Q.; OLIVEIRA JUNIOR, R. C.; GENTIL, R. S.; FERREIRA, E. M. Avaliação do efeito do bagaço de cana-de-açúcar in natura obtido por dois métodos sobre o desempenho e o comportamento ingestivo de bovinos de corte. Arquivo Brasileiro de Medicina Veterinária e Zootecnia, Belo Horizonte, v. 60, n. 3, p. 698-704, 2008.

REIS, R. A.; RODRIGUES, L. R. A.; RESENDE, K. T.; PEREIRA, J. R. A.; RUGGIERI, A. C. Avaliação de fontes de amônia para o tratamento de fenos de gramíneas tropicais. 1. Constituintes da parede celular, poder tampão e atividade ureática. Revista Brasileira de Zootecnia, Viçosa, MG, v. 30, n. 3, p. 674-681, 2001.
SANTANA JÚNIOR, H. A.; SILVA, R. R.; CARVALHO, G. G. P.; CARDOSO, E. O.; MENDES, F. B. L.; PINHEIRO, A. A.; ABREU FILHO, G.; DIAS, D. L. S.; BARROSO, D. S.; SILVA, F. F.; TRINDADE JÚNIOR, G. Comportamento ingestivo de novilhas suplementadas a pasto sob nutrição compensatória. Archivos de Zootecnia, Córdoba, v. 62, n. 237, p. 61-71, 2013.

SANTANA JÚNIOR, H. A.; SILVA, R. R.; CARVALHO, G. G. P.; SILVA, F. F.; MENDES, F. B. L.; ABREU FILHO, G.; TRINDADE JÚNIOR, G.; CARDOSO, E. O.; BARROSO, D. S.; PEREIRA, M. M. Correlação entre digestibilidade e comportamento ingestivo de novilhas suplementadas a pasto. Archivos de Zootecnia, Córdoba, v. 61, n. 236, p. 549-558, 2012.

SILVA, D. J.; QUEIROZ, A. C. Food analysis: chemical and biological methods. $2^{\text {th }}$ ed. Viçosa, MG: UFV, 2002. $235 \mathrm{p}$.

SISTEMA DE ANÁLISES ESTATÍSTICAS E GENÉTICAS - SAEG. Sistema de análises estatísticas e genéticas. versão 9.1. Viçosa, MG: Fundação Arthur Bernardes, UFV, 2007.

SNIFFEN, C. J.; O'CONNOR, J. D.; VAN SOEST, P. J.; FOX, D. G.; RUSSELL, J. B. A net carbohydrate and protein system for evaluating cattle diets: II. Carbohydrate and protein availability. Journal of Animal Science, Champaign, v. 70, n. 11, p. 3562-3577, 1992.

VAN SOEST, P. J. Nutritional ecology of the ruminant. $2^{\text {th }}$ ed. Ithaca: Cornell University Press, 1994. 476 p.

VAN SOEST, P. J.; ROBERTSON, J. B.; LEWIS B. A. Methods for dietary fiber, neutral detergent fiber, and nonstarch polyssacharides in relation to animal nutrition. Journal Dairy Science, Champaign, v. 74, n. 10, p. 5833597, 1991.

WEISS, W. Energy prediction equations for ruminant. In: CORNELL NUTRITION CONFERENCE FOR FEED MANUFACTURERS, 61., 1999, Ithaca. Proceedings... Ithaca: Cornell University, 1999. p. 176-185.

WELCH, J. G. Rumination, particle size and passage from the rumen. Journal of Animal Science, Champaign, v. 54, n. 4, p. 885-894, 1982.

WELCH, J. G.; HOOPER, A. P. Ingestion of feed and water. In: CHURCH, D. C. (Ed.). The ruminant animal: digestive physiology and nutrition. Englewood Cliffs: Reston, 1988. p. 108-116. 
